\section{International Scientific Journal \\ Theoretical \& Applied Science}

p-ISSN: 2308-4944 (print) e-ISSN: 2409-0085 (online)

Year: $2014 \quad$ Issue: $10 \quad$ Volume: 18

Published: $30.10 .2014 \quad$ http://www.T-Science.org
Victoria Alexandrovna Temnyshova assistant of the Department of «Land management and land cadastre» Volgograd state agricultural University, Russia viktoriatem@mail.ru

SECTION 35. Immovable property. Land relations.

\title{
FORMATION OF A RATIONAL ORGANIZATION OF THE TERRITORY ON ENVIRONMENTAL LANDSCAPE BASED IN VOLGOGRAD REGION
}

Abstract: As a result, there is an increase in economic activity scale erosion, desertification, pollution of surface and ground water, leading in some cases to the degradation of the productive capacity of agricultural land. Under such conditions, land use planning at the most obvious and it becomes necessary for the improvement of the basic theoretical aspects on the basis of ecological and landscape.

Key words: agricultural land, erosion, landscape.

Language: English Russian

Citation: Temnyshova VA (2014) FORMATION OF A RATIONAL ORGANIZATION OF THE TERRITORY ON ENVIRONMENTAL LANDSCAPE BASED IN VOLGOGRAD REGION. ISJ Theoretical \& Applied Science 10 (18): 37-40. doi: http://dx.doi.org/10.15863/TAS.2014.10.18.9

\section{ФОРМИРОВАНИЕ РАЦИОНАЛЬНОЙ ОРГАНИЗАЦИИ ТЕРРИТОРИИ НА ЭКОЛОГО- ЛАНДШАФТНОЙ ОСНОВЕ НА ТЕРРИТОРИИ ВОЛГОГРАДСКОЙ ОБЛАСТИ}

Аннотация: В результате хозяйственной деятельности наблюдается возрастание масштабов эрозии, опустынивания, загрязнения поверхностных и грунтовых вод, приводящчих в ряде случаев к деградации производительного потенциала агроландшафтов. В таких условиях при землеустроительном проектировании наиболее очевидным и необходимым становится совершенствование основных теоретических положений на эколого-ландиафтной основе.

Ключевые слова: сельскохозяйственные угодья, эрозия, ландиафт.

Главным производственным потенциалом всего агропромышленного комплекса на территории Волгоградской области являются земельные ресурсы. Большая часть области представлена сельскохозяйственными угодьями.

Почвы сельскохозяйственных угодий основная часть почвенных ресурсов области, среди которых преобладает пашня. Площадь Волгоградской области составляет 11288 тыс. га, за землепользователями, входящими в состав АПК, закреплено 9451,2 тыс. га. за десятилетний период площадь обрабатываемых земель сократилась, а площадь пастбищ увеличилась.

В настоящее время в хозяйствах всех форм собственности в полевых севооборотах не используется около одного миллиона гектаров обрабатываемых земель, причем их выведение из оборота осуществляется без учета плодородия рабочих участков полей и их кадастровой оценки.

Специфика почвенного покрова Волгоградской области - его неоднородность, которая усиливается с северо-запада на юговосток.

Волгоградская область расположена в пределах двух почвенных зон - черноземной и каштановой. 


\section{Современная структура земельных ресурсов Волгоградской области}

\begin{tabular}{|c|c|c|c|}
\hline \multirow{2}{*}{$\begin{array}{c}\text { Наименование сельскохозяйственных } \\
\text { угодий }\end{array}$} & \multicolumn{3}{|c|}{ Площадь угодий, га } \\
\cline { 2 - 4 } & 2006 г. & 2010 г. & 2013 г. \\
\hline Пашня & 5892095 & 5848600 & 5798507 \\
\hline Залежь & 4767 & 4302 & 4885 \\
\hline Многолетние насаждения & 43480 & 44168 & 10477 \\
\hline Сенокосы & 206355 & 206421 & 201770 \\
\hline Пастбища & 2616609 & 2657817 & 2652639 \\
\hline Итого земель & 8668278 & 8761308 & 8668278 \\
\hline
\end{tabular}

Таблица 2

Использование пашни по почвенно-климатическим зонам Волгоградской области

\begin{tabular}{|c|c|c|c|}
\hline \multirow{2}{*}{ Природные зоны } & \multicolumn{3}{|c|}{ Площадь пашни, тыс. га } \\
\cline { 2 - 4 } & имеющаяся & в обработке & неиспользуемая \\
\hline Степная черноземных почв & 1887,8 & $1817,7 / 96,3 \%$ & $70,1 / 3,7 \%$ \\
\hline Сухостепная темно-каштановых почв & 1073,9 & $917,7 / 85,5 \%$ & $156,2 / 14,5 \%$ \\
\hline Сухостепная каштановых почв & 2275,8 & $1798,9 / 79 \%$ & $476,9 / 21 \%$ \\
\hline Полупустынная светло-каштановых почв & 630,8 & $423,4 / 67,1 \%$ & $187,8 / 29,7 \%$ \\
\hline Итого по области & 5868,3 & $4957,6 / 84,7 \%$ & $891,0 / 15,3 \%$ \\
\hline
\end{tabular}

В последние годы лишь около 51\% занимают сельскохозяйственные угодья от общей территории Волгоградской области, отмечается устойчивая тенденция сокращения продуктивных площадей.

Из около 8,7 млн. га сельскохозяйственных угодий области, 2,2 млн. га подвержено водной эрозии, из них 1,3 млн. га пашни. Площадь размываемых склоновых земель составляет 200 тыс. га, а непосредственно занятой оврагами - 63,9 тыс. га. Площадь смытых в разной степени почв составила 2 249,1 тыс. га на сельскохозяйственных угодьях и 1 348,6 тыс. га на пашне, таким образом, в этот процесс вовлечено около $41 \%$ сельскохозяйственных угодий.

Ветровая эрозия, или дефляция почв, отмечена на 89,1 тыс. га сельскохозяйственных угодий и на 47 тыс. га пашни.

Вмешательство человека привело к трансформации экосистем в агроэкосистемы с катастрофическими изменениями баланса, в т. ч. не восполняемыми изъятиями биомассы. Наиболее ощутимыми оказались изменения в почвенном покрове, обусловленные пастбищной дигрессией и обработкой почвы: разрушение почвенной структуры, ухудшение воднофизических характеристик почвы (в первую очередь ее плотности, воздушного режима; инфильтрационной способности), еe дегумификация, - что привело к серьезным изменениям водного баланса в ландшафте, ухудшению влагообеспеченности и, в конечном итоге, уменьшению продуцирования фитомассы, возникновению эрозии и дефляции, общему истощению (деградации) природной среды.
В целях ослабления, прекращения процессов деградации и восстановления экосистем, в первую очередь почвенного покрова, предлагается концепция природопользования, направленного на стабилизацию структурно-функциональных свойств ландшафта (иерархии его подсистем и процессов энергомассопереноса) путем адаптации (приспособления) хозяйственной деятельности, в т. ч. в земледелии (структуры посевных площадей, севооборотов, технологий выращивания сельскохозяйственных растений с учетом их требовательности к условиям среды обитания и т. п.), к этим свойствам и максимального приближения агроландшафтов, характерных для естественных ландшафтов.

Адаптивно-ландшафтный принци предполагает неистощительный (сбалансированный, компенсаторный) характер землепользования в отличие от сложившегося ныне, обусловленного совокупностью исторических, социально-экономических и других факторов и приведшего к деградации растительности, почв, животного мира и в целом среды обитания человека.

В системе сухого земледелия Волгоградской области основное внимание уделялось земледельческим проблемам, главной задачей было не рациональное использование, получение только максимального количества продукции. Не учитывались другие составные части экологоландшафтного обустройства сельскохозяйственных земель.

Адаптивно-ландшафтное земледелие - это сельскохозяйственная деятельность, при которой 
максимально учитываются особенности природных и антропогенных ландшафтов, требовательность сельскохозяйственных культур к условиям произрастания, оптимально реализуется ресурсный потенциал, каждый земельный участок используется с учетом его агроэкологической оценки.

В агротехнологиях таких систем учитывается также сельскохозяйственный уклад товаропроизводства.

Целью адаптивно-ландшафтного земледелия является создание таких условий, при которых сохранялись бы природные ландшафты, улучшались агроландшафты и восстанавливались деградированные земли.

Основные принципы разработки системы адаптивно-ландшафтного земледелия следующие: 1) системный подход, предполагающий создание агроэкосистем разного уровня организации, которые имеют множество типов и уровней связи как в пределах системы, так и между системами разных типов;

2) адаптивность систем земледелия к природно-экономическим и экологическим условиям (адаптация культур и сортов к конкретным условиям произрастания, адаптация технологий, адаптивное управление природноресурсным потенциалом и т. д.);

3) устойчивость функционирования агроэкосистем, достигаемая оптимизацией элементов систем земледелия с учетом ресурсного потенциала агроландшафтов;

4) почвозащитная и природоохранная направленность, обеспечивающая снижение до допустимых пределов эрозии и дефляции почв, предотвращение загрязнения почв и среды биогенными веществами, прекращение деградации почв и получение экологически чистой продукции;

5) социально-экономическая

целесообразность, предусматривающая рациональное использование антропогенных ресурсов за счет применения наиболее экономически эффективных мероприятий, приемов и их сочетаний (оптимальная структура посевов, севооборотов, сортов, удобрений, мелиорации и др.).

Определяющим

моментом агроландшафтного обоснования организации землепользования является типизация земель (выделение контуров по однородным агроэкологическим условиям) и определение характера их использования, а также применение технологий, приемов и мероприятий, обеспечивающих нормальное функционирование агроэкосистем. Критериями для выделения разных групп земель являются характер гидрологических и эрозионных процессов, состояние почв, местонахождение в рельефе, доступность для механизации и др.

В основу оценки территории области как объекта землепользования положен принцип разделения на природно-территориальные комплексы, отличающиеся генетической и гранулометрической общностью почв и почвообразующих пород, общностью рельефа и, как следствие, сельскохозяйственной специализации. Такой принцип выделения агроландшафтов в полной мере отвечает задачам организации адаптивно-ландшафтного землепользования.

Распределение типов и подтипов почв по типам местности представляет важную практическую информацию о качественном состоянии земель в Волгоградской области и их рациональном аграрном освоении. Позволит выявить количество земель, нуждающихся в адаптационном ведении хозяйства с применением комплекса агротехнических мероприятий, задача которых, в конечном итоге, должно сводится к увеличению объемов сельхозпродукции без нарушения экологического баланса конкретной территории или агроландшафта.

Переход к ландшафтно-экологическим системам земледелия обеспечит условия для экологически безопасного и экономически целесообразного использования природных и антропогенных ресурсов с целью получения экологически чистой продукции.

В сложившихся условиях ориентирование на региональный и зональный принципы ведения сельского хозяйства не в состоянии обеспечить разработку и внедрение действенных мер защиты природной среды.

Это побудило к сближению ландшафтноэкологической и сельскохозяйственной идеологий природопользования и послужило толчком к формированию адаптивно-ландшафтных принципов природопользования, т. е. к переходу от зонально-регионального уровня адаптивного обустройства сельскохозяйственных ландшафтов зоны, провинции, районы) на уровень локальных таксонов ландшафтов, местностей, урочищ и подурочищ.

При физико-географическом районировании выделялись 2 зоны (степная и полупустынная), 8 провинций и 22 района, при природносельскохозяйственном и почвенногеографическом - 3 зоны (степная, сухостепная и полупустынная), 5 провинций и 7 природносельскохозяйственных районов.

Территория Волгоградской области районирована с учетом природных факторов и компонентов ландшафтов и их морфологичесой структуры, что позволяет дифферинцировать характер использования земель и планировать земледельческую деятельность со сложившимися экологическими условиями и характером 
деградационных процессов.

Ландшафтно-экологический подход к решению вопросов организации и устройства территории является объективной необходимостью сельскохозяйственною природопользования, так как он обеспечивает наиболее полный учет функциональных связей между компонентами природы и элементами агроландшафтов.

\section{References:}

1. (2011) Land Code of the Russian Federation. as amended., From 07.12.2011 N 417-FZ Consultant Plus. - Mode of access: http://www/consultant.ru/popular/earth/

2. (2014) Forest Code of the Russian Federation. as amended., From 12.03.2014 N 200-FZ) Consultant Plus. - Mode of access: http://www/consultant.ru/popular/earth/

3. Vorobyov AV (2004) Land Volgograd region on 01.01.2004, ed. AV Vorobyov Volgograd, LLC "Acad" Volgograd, 48.

4. Vorobyov AV (2003) Land Fund of the Volgograd region, ed. A.V.Vorobeva Volgograd, Ed. "Volgograd", 48.

5. (1997) Land of the Volgograd region. ed. AV
Vorobyov. Volgograd, village-2. - 132.

6. Isachenko AG (1991) Landscape and physicogeographical regionalization. Moscow: High School, 366.

7. Lopyrev MI, et al (2004) Physical organization of the territory: a tutorial. Voronezh.gos. agrarian. Univ. Voronezh FSEIHPE VSAU, 170.

8. (2004) Summary of materials on land monitoring of the Volgograd region. Office of the Federal Real Estate Cadastre Agency for the Volgograd region. - Volgograd, Volume 1, 30.

9. Chursin BP (1992) Soil resources. Soilenvironmental problems in the steppe agriculture. - Pushchino, pp. 23-39. 